\title{
Geological Mapping by Use of Computer-Enhanced Imagery in Western Saudi Arabia
}

GEOLOGICAL SURVEY PROFESSIONALAAPER 1153

Prepared in cooperation with the Directorate General of Mineral Resources, Ministry of Petroleum and

Mineral Resources, Kingdom of Saudi Arabia 



\section{Geological Mapping by Use of Computer-Enhanced Imagery in Western Saudi Arabia}

By H. W. BLODGET and G. F. BROWN

GE O L G I A L S U R VEY PR OFE S I O N A L PAPER 1153

Prepared in cooperation with the Directorate General of

Mineral Resources, Ministry of Petroleum and

Mineral Resources, Kingdom of Saudi Arabia

An attempt to separate geologic units on the

basis of land surface reflectance as shown

on satellite imagery

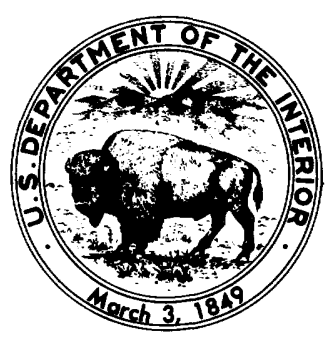




\title{
UNITED STATES DEPARTMENT OF THE INTERIOR
}

\author{
JAMES G. WATT, Secretary \\ GEOLOGICAL SURVEY
}

Dallas L. Peck, Director

Library of Congress Cataloging in Publication Data

Blodget, H. W.

Geological mapping by use of computer-enhanced imagery in western Saudi Arabia.

(Geological Survey professional paper; 1153)

Bibliography: p.

Supt. of Docs. no.: I 19.16:1153

1. Geological mapping. 2. Geology-Saudi Arabia-Maps. 3. Landsat satellites. I. Brown, Glen Francis, 1911-joint author. II. Title. III. Series: United States. Geological Survey. Professional paper; 1153. QE36.B53 526.9'823 80-607149

For sale by the Superintendent of Documents, U.S. Government Printing Office Washington, D.C. 20402 


\section{CONTENTS}

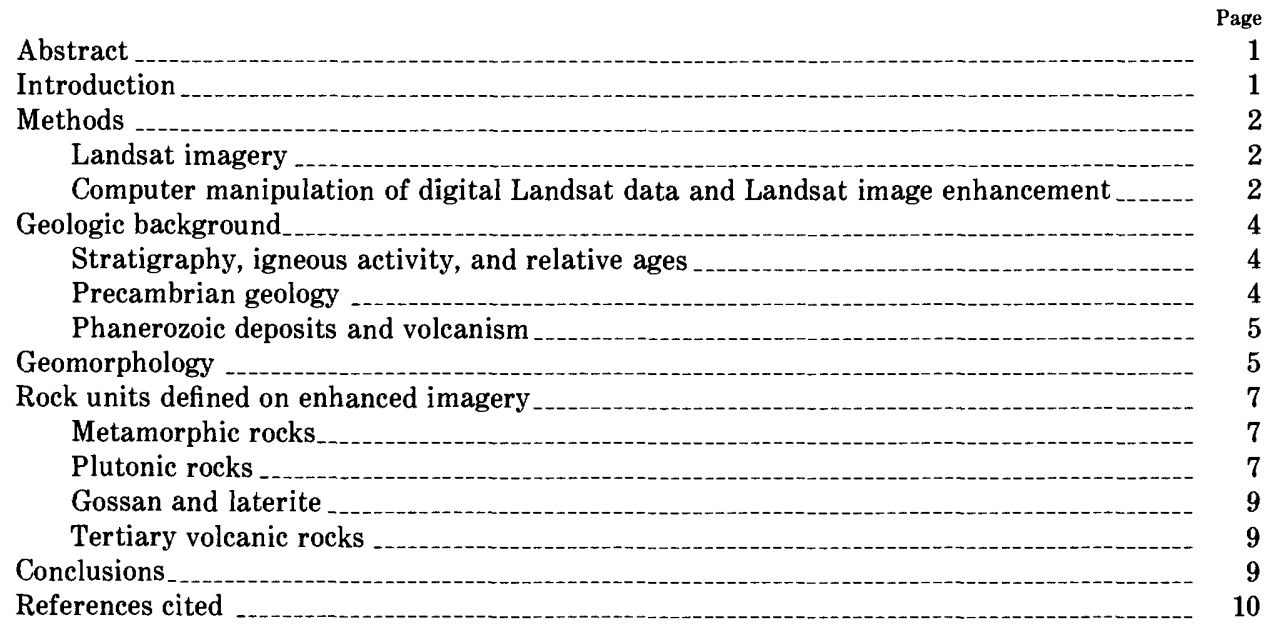

\section{ILLUSTRATIONS}

[Plates are in pocket]

Plate 1.-Imagery and geology of the Al Wajh area (test area 1), northwestern Saudi Arabia. 2.-Imagery and geology of the Zahrān area (test area 2), southwestern Saudi Arabia. 



\title{
GEOLOGICAL MAPPING BY USE OF COMPUTER-ENHANCED IMAGERY IN WESTERN SAUDI ARABIA
}

\author{
By H. W. BLODGET ${ }^{1}$ and G. F. BRown
}

\begin{abstract}
Several computer-based classifications and image-enhancement techniques that use Landsat multispectral scanner (MSS) data are compared to determine their value as aids for geologic mapping in the low-latitude desert of western Saudi Arabia. Discrimination among various surface materials can be improved with Landsat data manipulated by a variety of computer algorithms. The most effective method described is the simultaneous use of two differently computerenhanced Landsat MSS color-composite images. These were constructed using the ramp-cumulative distribution function contrast stretch and the ratio-contrast stretch algorithms, the latter using MSS bands $\% 5,5$, and $\% /$ projected through blue, green, and red filters, respectively. The contrast-stretched imagery increases the separation of low-spectral values of picture elements in the display at the expense of the brighter values and has proven especially useful for identifying geological structures. The ratio-contrast stretch imagery, on the other hand, provides the greatest capability for rock discrimination.

Computer processing of MSS data obtained at high sun angle (summer) provided significantly better rock-class separability than was attained using low sun angle (winter) data. The winter data, however, provided more detailed structural information. The spectral response of individual rock classes is also influenced by a wide variety of factors, such as weathering, soil development, desert varnish, eolian sand blasting, and abundance of vegetative cover-all these factors must be considered when making geologic interpretations.

This study demonstrates that digital Landsat data manipulated by various computer techniques can produce imagery that greatly increases the geologic interpretability and can be used successfully to aid geological mapping at regional scales.
\end{abstract}

\section{INTRODUCTION}

Geologic mapping of the crystalline rocks in the Arabian segment of the Arabian-Nubian Shield (pl. 1) was begun on a systematic basis in 1950 by the U.S. Geological Survey at the request of the late King Abdul Aziz ibn Saud. The prime concern of the Government of Saudi Arabia was finding potable water supplies for populated and agricultural areas. A secondary objective was to locate and evaluate economic raw materials and (or) ore deposits. Out of necessity, the early work was of a reconnaissance nature and consisted mainly of the preparation of base maps that showed roads, trails, and watering points. Those maps were published at a scale of 1:500,000. After an initial demonstration photographic project conducted by the U.S. Geological Survey, the late King Faisal ibn Saud, then Viceroy of the Hejaz, agreed to finance complete aerial photographic coverage. The precise location of these aerial photographs had to be largely determined by using shoran geodetic control, for the inhospitable terrain made surface surveying extremely difficult. The photographs were then

\footnotetext{
${ }^{1}$ National Aeronautics and Space Administration.
}

made into mosaics which served as a base for the first accurate maps on which the reconnaissance geology was drawn (examples are pls. $1 A$ and $2 A$, the two test areas discussed in this report).

Mapping on a scale of 1:100,000 was begun in 1961 . However, only during the last 14 years, with the availability of fixed-wing and helicopter transportation and full-laboratory, -geophysical, -geochemical, and -diamond-drilling support, has it been possible to map in the desired detail for specific economic targets. At present, about one-half of the shield has been mapped at this scale and rather intensively prospected. This work has been accomplished by several national teams under contract to the Directorate General of Mineral Resources, as well as by the U.S. Geological Survey, in cooperation with the Directorate staff. Currently, the Government of Saudi Arabia is preparing a new series of geologic maps at a scale of 1:250,000. For this purpose, computer-enhanced satellite imagery provides a valuable new aid for geologic interpretation and the continuing search for water and raw materials.

In 1972, satellite imagery became available for the entire Arabian Peninsula and now provides synoptic views of many aspects of the terrain. These images are now used routinely to supplement the aircraft photography in regional mapping efforts. Standard Landsat color-composite images show relief, drainage, and the major differences in reflectivity of different rock types. With sufficient geological mapping on the land surface for local controls, the standard Landsat imagery can be used as a suitable orthographic base that has greater accuracy than most photographic mosaics have. This is especially true in areas where there is much relief in the terrain.

This study is an outgrowth of a doctoral thesis prepared by the senior author for presentation at George Washington University. The test areas discussed herein are adjacent, with some overlap in the Zahrān area, to two that Blodget (1977) described in his thesis (pl. 1). The test areas were selected with the intent to supplement and extend over a wider area containing a greater variety of diverse rock types the concepts formulated by Blodget.

Acknowledgments. - The interpretation of the computer-enhanced Landsat imagery would not have been possible without access to the unpublished geologic maps by S. Okumi, K. Komura, and T. Hatanaka of the Japan Geological Survey; John Kemp and C. Pellaton of the Bureau de Recherches Géologiques et Minières of 
France; and R. E. Anderson, W. R. Greenwood, and D. B. Stoeser, U.S. Geological Survey. The authors are grateful to these men and their organizations.

The staff of the Directorate General of Mineral Resources, Kingdom of Saudi Arabia, made the field work possible and cooperated in the formulation of the concepts. Field support in the southern test area by Abdulaziz Bagdady is gratefully acknowledged. Salman Bloch, U.S. Geological Survey, did much of the geological compilation and reviewed the report.

The color-composite maps of the Al Wajh area were prepared by Seiscom Delta, Inc.; the index mosaics and color composite of the Z̧ahrān area were made by the General Electric $\mathrm{Co}^{2}{ }^{2}$

The report was prepared at the suggestion of John Reinemund, U.S. Geological Survey, who reviewed the manuscript and suggested its present form. Raymond Fary, Wenonah Bergquist, Alfred Chidester, and David Davidson also reviewed the manuscript. Wenonah Bergquist helped with the preparation of the illustrations and suggested methods of presentation. J. G. Moik of the National Aeronautics and Space Administration (NASA), Goddard Space Flight Center, created the computer-enhanced imagery. Paul Lowman, NASA, gave constructive advice regarding geological applications of satellite imagery and reviewed the paper.

\section{METHODS}

\section{LANDSAT IMAGERY}

Remote-sensing techniques have been used to complement geologic field mapping for more than a half century. The techniques, however, have been largely limited to the interpretation of standard black and white aerial photography. The traditionally successful photointerpretation techniques have more recently been extended for use with Landsat imagery that became available on a routine basis in the latter half of 1972 . Most of the currently available Landsat imagery has been provided by the multispectral scanners (MSS) carried on the Landsat 2 and 3 satellites. These scanners record reflected visible and near-infrared radiation from terrestrial surfaces in each of four spectral bands which have been designated as follows: MSS band 4 for the 0.5-0.6 micrometer $(\mu \mathrm{m})$ (green) wavelength interval, MSS band 5 for the $0.6-0.7 \mu \mathrm{m}$ (red) interval, and MSS bands 6 and 7 for the 0.7-0.8 $\mu \mathrm{m}$ and 0.8-1.1 $\mu \mathrm{m}$ (near-infrared) intervals. The radiation is sensed by an array of detectors on the spacecraft and then encoded into a digital format that furnishes a continuous data stream for radio transmittal to ground receiving stations. These data are recorded on tape at the receiving station and then shipped to the NASA Data Processing Facility. ${ }^{3}$ There the uncorrected data tapes are re-

\footnotetext{
${ }^{2}$ Any use of trade names and trademarks in this publication is for descriptive purposes only and does not constitute endorsement by the U.S. Geological Survey.

${ }^{3}$ These procedures were changed February 1, 1979. (See U.S. Geological Survey, Landsat Data Users Notes, Issue 8, p. 4-5.)
}

formatted and translated to gray-scale values prior to being converted to imagery for each of the four bands. The original data can also be translated to digital computer-compatible tapes. The standard Landsat image products that are available for general distribution consist of several black and white photographic formats made from each of the MSS bands from master 70-millimeter $(\mathrm{mm})$ film. In addition, color-composite imagery that simulates the familiar near-infrared false-color photography can be constructed photographically by using the appropriate black and white film and color-filter combinations.

Photogeologists readily accepted these Landsat photographic products, for the data are intelligible and useful. The immediate advantage of this small-scale, high-resolution imagery, of course, is for construction or revision of small-scale regional maps. An area 185 $\mathrm{km}^{2}$ is covered in each scene, and enlargements from the $70-\mathrm{mm}$ master film can be made up to a scale of $1: 250,000$ without introduction of serious graininess.

\section{COMPUTER MANIPULATION OF DIGITAL LANDSAT DATA AND LANDSAT IMAGE ENHANCEMENT}

Experience indicates that only a small part of the spectral information contained in the multispectral Landsat data is shown in the standard film products. During the past several years, an increasing amount of Landsat-based research has involved computer manipulation techniques designed to enhance and (or) classify specific discipline-defined parameters (Siegal and Gillespie, 1979). Interactive multispectral classification systems using both parallelepiped and Bayesian maximum-likelihood algorithms have been formulated and are commercially available from several manufacturers. These systems have been designed to accept several classes of multispectral data but have been particularly successful in using Landsat digital MSS input for small-scale thematic mapping. In California, for example, regional agricultural activities can be inventoried and monitored to accuracies adequate for many planning activities (Colwell, 1973). The ability to identify temporal changes further provides the capability to rapidly update cultural maps, to monitor strip mining and restoration activities, to quickly assess damage caused by major floods, and a host of similar tasks.

Attempts to use these classification systems to distinguish differences among rock types were much less successful than mapping of vegetation had been elsewhere. Computer-training sites were established for a wide variety of rock classes in the Sahl al Maţrān area in the northwest part of the country (Blodget and others, 1975). The only rock types that could be classified with any consistency were those exposed in nearly horizontal surfaces. These included such lithologic units as fissure basalt flows and alluvium. In addition, in some areas under the proper conditions, it appeared possible 
to relate specific alluvial classes to the lithology of their provenance. Igneous and metamorphic assemblages in very highly dissected terrane make up most of the Arabian Shield. Obtaining representative training areas required for computer classification of specific rock units within these areas ranged from very difficult to impossible. The principal reason for this is that spectral reflectances from specific lithologies are strongly influenced by differences in surface slope and attitude and by shadows inherent in the rugged land surfaces. Multispectral classification thus appears to have only limited application for rock identification in the shield areas of Saudi Arabia.

Landsat image enhancement. -Several digital procedures have also been devised to enhance specific parameters contained in Landsat imagery. These techniques range from the relatively simple single-band contrast enhancement to two-dimensional filtering in spatial or Fourier domain and complex cluster analyses, sometimes coupled with ratioing of spectral bands (Rowan and others, 1974). The two computer-enhanced products that proved most useful for geologic mapping in the Sahl al Maţrān test area were (1) color composites of individually contrast-enhanced MSS bands and (2) contrast-enhanced band ratios.

The Landsat MSS system is designed to accommodate the entire dynamic range in scene brightness that may be encountered during the whole of the near-global coverage of the satellite, and this can be equated to 256 shades of gray on film. Consequently, the brightness range of any specific scene can be stretched to fill the entire dynamic range of the medium. Several types of stretches have been devised to increase the contrasts among specific parameters; these can be either linear or nonlinear. The stretch considered optimum for increasing contrast among the rock units of northwestern Saudi Arabia uses the ramp-cumulative distribution function (CDF), which is formed by defining the sum of succeeding values of groups of pixels (picture elements) in the brightness distribution, to approximate a linear ramp function (Goetz and others, 1975, p. 112). The stretched data for the individual MSS bands can further be combined to form color-composite imagery having a wide range of color. This type of stretch increases the separation among pixel values in the low-radiance areas of a display at the expense of separation in the brighter areas and is ideal in the crystalline Arabian Shield complex, where igneous and metamorphic rocks all tend to have low reflectance.

To further increase contrast among surface features, MSS band-paired data can be ratioed prior to application of the stretch algorithms; this reduces the environmental effects on the surface reflectance. Ratio-stretch data sets composited into color imagery provided the single best enhancement products for rock discrimination in northwestern Saudi Arabia. This enhance- ment procedure consists of three fundamental steps: (1) paired data from selected MSS bands are ratioed pixel by pixel, (2) the resultant values from each pair are then stretched using the ramp-CDF stretch algorithm, and (3) the values are combined into color-composite imagery using various combinations of filters and lightexposure intensities. In this procedure, alternative ratio and filter combinations can be used to optically enhance specific rock classes. In a northwestern Arabian test site, a combination of MSS bands $\% 5,56$, and $5 \%$ stretchedratio values projected through blue, green, and red filters, respectively, provided the best combination for lithologic discrimination (Blodget and others, 1975). The use of ratio values allows for a substantial increase in contrast by reducing brightness variations due to topography, shadowing, and reflectance-angle variation. The ratio values for any single scene, however, generally have a narrow range and must be contrast stretched to further enhance the visibility of the spectral differences.

Ratio-stretched color-composite images of the same scene vary with differences in sun angle. On one such enhanced image made from low winter-sun angle Landsat data of the Sahl al Maţrān test site, it was possible to recognize two rock types in addition to the ones that could be discriminated by the earlier use of digital classification systems. These included a broad class of granites and a hornblende-biotite-quartz monzonite, both of which had been defined in the field by Hadley (1973a). The remaining igneous units, as well as all the metamorphic rocks that had been mapped by Hadley, were still not readily separable.

Subsequent enhancement of MSS data for the same test site but obtained during a July satellite pass, using the identical digital techniques (Blodget, 1977), produced a considerably greater correspondence between the spectral units and the rock units described in the field by Hadley (1973a, 1974, 1975). The increased discrimination capability was obviously due to the higher sun angle and resultant shadow reduction in the summer scene.

Although the contrast enhancement of ratios commonly provides an excellent image for discriminating among rock types, the products suffer resolution reduction of a factor of about 3 below that of a color-composite image constructed using contrast stretch. In addition, the alluvium was commonly found to show the spectral characteristics of its parent rock, and this makes identification of outcrop margins difficult. These margins, as well as fault lines and other structural features dependent on relief (see pl. $1 C$ and $D$ and pl. $2 C$ ), are generally considerably better defined on the MSS color composites of stretched images. Because of these factors, images made by using both of these enhancement techniques should be used in complementary roles for optimum use of data in geologic interpretation. 
Because of the success of enhanced Landsat imagery for rock discrimination in the Sahl al Matrān test site (Blodget, 1977), similar enhanced imagery was made for two other areas of the Arabian Shield to complement an active geologic mapping program. These are the $\mathrm{Al}$ Wajh area (test area 1, pl. 1) immediately west of the Sahl al Matrān test site and the extremely mountainous southwestern area of Saudi Arabia near the town of Zahrān (test area 2) in the Asir. In this report, we correlate computer-enhanced imagery derived from the Landsat multispectral scanner system with 1:100,000-scale geology mapped on the ground in the two geologically diverse areas. We have also attempted extrapolation of meager geologic ground-reconnaissance data through the use of the characteristics of rock reflectances as seen in the enhanced imagery.

Plate 1 illustrates the geology of test area 1 in the northern part of Saudi Arabia, and plate 2 illustrates test area 2 , which is in the southern part.

Plates $1 B$ and $2 B$ show standard Landsat colorcomposite imagery of test areas 1 and 2 , respectively, along with overlays compiled using the best available geological data. When more than one Landsat image is required to obtain complete coverage of a study area, two frames can be combined to maintain spectral continuity by directly processing several computercompatible satellite tapes into Landsat mosaics. Plate $1 B$ provides an example of such a multiscene area.

\section{GEOLOGIC BACKGROUND}

\section{STRATIGRAPHY, IGNEOUS ACTIVITY,} AND RELATIVE AGES

The test areas for computer-enhanced imagery were chosen so as to include nearly all the major rock units of the Arabian Precambrian shield and some Phanerozoic outcrops (see explanations for pls. $1 B$ and $2 B$ ). The Precambrian and Cambrian assemblages range in age from about 1 billion to 510 million years, according to radiometric isotope measurements, and span at least three orogenic events. The oldest of these events produced lineations that were formed by a combination of schistosity, fold axes, and faults. These trend northeast and may possibly be an interrupted extension of the Kibaran or Irumidian belt in East Africa. The next younger event produced the major Hejaz orogenic-cycle trend which in general produced north-trending lineations. The youngest orogenic event was the Najd movement, and this consisted primarily of sinistral faulting that trended to the northwest. Metamorphism of the rocks within both test areas is diverse, ranging from essentially unmetamorphosed sedimentary and igneous rocks through polymetamorphosed zones, which range from greenschist facies generally imposed on amphibolite facies to gneissic and granitoid cores of possible anatectic origin. The tectonic events were accompanied or followed by outpourings of basaltic, andesitic, dacitic, and rhyolitic lavas, as well as invasions of hypabyssal and plutonic rocks that ranged from narrow dikes to batholiths. Intrusive igneous rocks range from generally serpentinized ultramafic, through gabbro, to peralkaline granite composition. Although most of these plutonic rocks are calc-alkaline, the oldest are in general calcic, whereas the youngest are generally alkaline and peralkaline.

The excellent exposures and diverse rock types present an opportunity to analyze the various types of satellite imagery and to extend geologic interpretation from areas studied in considerable detail on the ground into areas where only reconnaissance studies have been made. The reference sources of geologic data for the southern area have not been published, and thus the geologic sketch map based on enhanced images (pl. 2B, $C$, and $D$ ) and accompanying explanation give only the rock-type symbols used by the three field geologists, R. F. Anderson, W. R. Greenwood, and D. B. Stoeser (pl. 2, Explanation). The same graphic approach has been used to designate outcrops in test area 1 where field work was done independently by several geologists, including S. Okumi, K. Komura, and T. Hatanaka of the Japan Geological Survey; C. Pellaton, John Kemp, and M. Bigot of the Bureau de Recherches Géologiques et Minières, France (pl. 1B); and one of us (G. F. B.).

\section{PRECAMBRIAN GEOLOGY}

The oldest dated rocks in the Arabian Shield consist of basaltic and andesitic flows, agglomerate, and tuff. Several gneissic belts, however, that are of questionable (probably mixed) ages may be older. Where shearing has not been too intense, the more massive flows have pillow structures indicative of marine eruptions. Where shearing has been severe, the flows have been altered to chloritic, sericitic, and graphitic or carbonaceous schists, many of which are talcose or serpentinized. The less abundant conglomeratic, graphitic, or carbonaceous shale, limestone, graywacke, and sandstone that were interbedded in the flows are now mostly schists in greenschist and amphibolite facies. Retrograde greenschist metamorphism is, in general, superposed on amphibolite-grade schists. The older "bedded" rocks are several thousand meters thick, are heavily volcanogenic, and are cut by calcic intrusive rocks. In several places, these are tonalite gneiss having batholithic dimensions.

An assemblage of somewhat younger bedded rocks, largely alkaline-calcalkaline andesite and dacite flows and tuffs, is also present but includes lesser amounts of metagraywacke, marble (generally dolomitic), chert, quartzite, and graphitic or carbonaceous schist. These are now mostly in the greenschist facies. This assemblage also includes quartz, sericite, and chlorite schists of uncertain origin and is intruded by calc-alkaline 
igneous stocks and batholiths composed of granodiorite gneiss and related rock types.

The Precambrian units, next younger than the mostly synkinematic plutonites that cut the above-mentioned beds, contain a wider variety of sedimentary units. These include graywacke, sandstone, siltstone, polygenic conglomerate, and related clastic rocks, with minor amounts of limestone and argillite. Most of the sediments contain grains of feldspar, angular quartz, and rock fragments derived from volcanic terranes. This suggests a single erosion and deposition cycle. Graded bedding and crossbedding are widespread, but ripple marks are less common; desiccation cracks and rain splatter marks are rare. Although this assemblage is largely of sedimentary origin, volcanism did not cease during this cycle. Andesite, rhyolite, and tuffs are present throughout the section but are most common in the younger sequences. These beds, both sedimentary and volcanic, are several thousand meters thick and are folded and faulted along northwest-trending shear zones several kilometers wide. Metamorphic grade ranges from essentially unmetamorphosed to amphibolite facies. Much slaty cleavage is developed where the rocks were derived from shale or tuff and metamorphosed to slate. Other beds are altered to sericitic and chloritic schists that now enclose amphibolite-grade infrastructures having gneiss and granite cores.

Folding of these beds was accompanied and followed by intrusion of calc-alkaline stocks and batholiths, most of which were composed of quartz monzonite and granite; these have been radiometrically dated by $\mathrm{Rb} / \mathrm{Sr}$ whole-rock isochrons and range from about 680 to 620 million years before present (m.y. B.P.). (Brown, 1972; Fleck, 1976).

Still younger, essentially unmetamorphosed flows, tuffs, and sediments that are composed of rhyolite, ignimbrite, water-laid tuffs, agglomerate, conglomerate, and wacke are confined to the northeastern part of the shield. Related siliceous dikes, however, are more widespread. Intrusive rocks associated with these younger sequences are largely alkaline-peralkaline granitic rocks characterized by sodic amphiboles. Isotopic ages $\left(\mathrm{K}^{40}-\mathrm{Ar}\right)$ range in age from 600 to 550 m.y. with a culmination at about 570 m.y. for the coarsegrained intrusive rocks. The latter generally form circular stocks or batholiths throughout the shield (Brown, 1972; Greenwood and others, 1975; Fleck and others, 1976). Gneisses in test area 1 were most likely formed during this time.

The youngest rocks are most likely of Cambrian age. They are also unmetamorphosed and are confined to the northwest-trending shear zones of the Najd transverse fault system. These rocks are composed of conglomerate, sandstone, cherty limestone, minor andesite, basalt, and rhyolite and are unconformable above all the older shield rocks; they are openly folded as a result of late movement along the underlying faults (Delfour, 1970; Baubron and others, 1976; Hadley, 1973b).

\section{PHANEROZOIC DEPOSITS AND VOLCANISM}

The lower Paleozoic strata consisting mostly of Ordovician sandstone encircle the crystalline shield and are essentially undisturbed. Although the sandstone is devoid of fossils in the lower several meters, it contains arthropod and gastropod trails in siltstone layers about $50 \mathrm{~m}$ stratigraphically above the crystalline basement. These siltstone layers are considered to be of Ordovician or youngest Cambrian age (Adolph Seilacher, written commun., 1973). The only Mesozoic rocks in the test sites are in a small outlier of Jurassic sandstone and limestone that remains as an erosional remnant $500 \mathrm{~m}$ above Ordovician sandstone on the high plateau near the Yemen border (pl. 2B, Jc, Ja; Anderson, 1978a). The oldest Tertiary material within the two test areas is made up of saprolitic and lateritic weathering products. These are mostly limited to areas covered with later Tertiary and Holocene flood-basalt flows. In the Sarat Plateau, 20 to $30 \mathrm{~m}$ of saprolite capped by laterite underlies 300 to $580 \mathrm{~m}$ of flood basalt. The latter ranges in age from 29 m.y. B.P. for the base to 25 m.y. B.P. on the crest (Brown, 1970; Overstreet and others, 1977).

The volcanic rocks that form the crests of several ridges within the test sites range in age from middle Oligocene to late Miocene. They are part of the most extensive volcanism of the Arabian Shield and are genetically related to the origin of the Red Sea. Although spreading probably began at the end of the Mesozoic, the most important rifting and widening seems to have been concentrated in middle and late Oligocene time, possibly somewhat earlier. This period of tectonic activity was followed by a quiescent, relatively static period that lasted until about 5 m.y. B.P. At that time, separation of the Arabian Shield from the Nubian Shield began again; it continued until the present (Girdler and Styles, 1974). During the quiescent period, a thick series of sediments that included as much as $2,800 \mathrm{~m}$ of evaporite deposits accumulated in the Red Sea depression that developed as a result of late Tertiary ramping of the flanks. These beds range from Miocene to Pliocene age and crop out along the coast (pl. 1B). The less soluble components together with Miocene coral coquina form terraces behind (east of) the elevated Pleistocene coral reefs (pl. $1 B$ ).

\section{GEOMORPHOLOGY}

Basement rocks in the low-latitude deserts of North Africa and the Middle East are commonly well exposed. Especially good exposures are found along the flanks of the Red Sea where ramping in connection with rifting has removed much of the surficial debris. The nearly level surfaces away from the scarps have been formed by classical desert pedimentation. 
Local sandstone outliers of probable Ordovician age that cap Jabal Tin (lat $22^{\circ} \mathrm{N}$., long $41^{\circ} 36^{\prime} \mathrm{E}$.) and Jabal Tamiyah (lat $25^{\circ} 35^{\prime}$ N., long $42^{\circ}$ E.) attest to an Early Paleozoic period of shield burial. Additional evidence for burial is provided by the presence of Cambrian (?), and Ordovician sandstone in the grabens of the southeast-trending Najd fault system along the northern edge of the shield. The Precambrian surface was later exhumed and further eroded by pediment extension throughout the rest of Phanerozoic time.

Postcratonization beveling is far advanced but not complete. Bornhardts, small inselbergs, and koppies are widely spaced on the grus plains of the older granitoid rocks, and younger posttectonic granites commonly form inselbergs or mountains. The latter are found mostly along the scarps of the rift where their relief is attributed to Cenozoic epeirogeny.

Sedimentary beds older than about 450 m.y. B.P. were at least partly stripped from the shield by Late Ordovician glaciation centered in North Africa (Beuf and others, 1971), especially in the northern reaches of the crystalline plains where deep-weathering profiles are absent. In addition, Carboniferous and Permian glaciation has been identified as far north as lat $14^{\circ} 30^{\prime} \mathrm{N}$. in Tigre Province, Ethiopia (Dow and others, 1971), and may have extended into western Arabia. The 950-m thickness of the Wajid Cambrian (?) and Ordovician sandstone at lat $19^{\circ} \mathrm{N}$. suggests, however, that Gondwanian (Carboniferous and Permian) glaciation scour was minimal, if it did indeed extend that far north.

Epeirogeny initiating increased fluvial action and aided by wind scour has been a far more potent erosional mechanism. The doming prior to, during, and following rifting caused orographic convection, especially in the monsoon belt in southern Arabia. The consequent fluvial erosion deposited $2,000 \mathrm{~m}$ of clastic rocks, mostly of continental origin, above the Miocene evaporite beds in the southern Red Sea trough (Gillmann, 1968).

The beveled surfaces that represent more than half the area of the shield are of three principal periods: the extensive older exhumed peneplains and pediplains and two younger pediments worn into the flanks of the Red Sea rift ramps. The opening of the Red Sea that began early in the Tertiary, or possibly during the Latest Cretaceous (Maestrichtian), furnished a new base level for pedimentation, which accompanied the widening of the rift from the Oligocene onward. This produced the beveled, somewhat dissected surface that rises from beneath the eastern edge of the coastal plain at about $50 \mathrm{~m}$ altitude, attaining an altitude of about $500 \mathrm{~m}$ above the Red Sea.

The youngest pediment along the coast lies along the eastern edge of the alluvial plain and represents pedimentation since the second stage of opening of the Red Sea. This surface is largely undissected even though several major wadis have cut channels now filled with gravel across it. It merges with coral reefs and alluvial fans. In most places it is less than $10 \mathrm{~km}$ wide and of ten is difficult to define because of the presence of superposed alluvial scree that extends down from the scarp mountains and discontinuously across the older pediment.

In the southern part of the shield, continued epeirogenic movement in connection with the rifting has tilted the pediplain and peneplain surfaces to the northeast. Along the northern beaches of the eastern Red Sea shore, it appears that the terraces are elevated from the 3-m surface at Jiddah to $520 \mathrm{~m}$ on Tiran Island near the mouth of the Gulf of Aqaba. The elevated surfaces are stepped benches from Jiddah northward, reflecting the intermittent character of the uplift, and are especially well developed between Al Wajh and the Gulf of Aqaba (pl. $1 C$ and $D$ ). The middle Tertiary pediment also rises to the northeast in this region (pl. $1 B$ ).

Whereas fluvial processes are dominant in the southern part of the shield, the effect of eolian erosion is more noticeable farther north. Rainfall is much less throughout the northern desert (probably less than $5 \mathrm{~cm}$ per year in most places), and mountain ranges are nearly barren of vegetation. The limited rain comes during the winter season and is associated with the southern part of the belt of prevailing westerly winds. Wind scour in an easterly direction is apparent on all aerial photographs and satellite imagery. The effect is most marked downwind from sources of sand and silt such as the Paleozoic sandstone that rims the northern edge of the shield and east of the grus plains on the shield where the older granitoids are exposed and weathered. Many surfaces are stripped of weathered material by windborne sandblast, and joints, faults, and sedimentary contacts are opened and widened. Because the initial openings are along zones where the meager rain or dew accumulates in depressions, frost action and the wide diurnal temperature range induce mineral separation by means of differential expansion and contraction upon heating and cooling. Thus, grains are loosened to a sufficiently small size to be windborne. One direct result is an emphasis of lineation patterns in the directions of the prevailing winds. Where airborne sand and silt are insufficient to serve as a scouring tool, the dark iridescent desert varnish may markedly change the spectral reflectance of the underlying rocks, especially if considerable iron and manganese are involved in the weathering process. Diorite or basalt, for example, commonly show desert varnish, and, if there is adequate abrasion to remove the varnish, shiny surfaces of desert polish are formed. Accumulation of desert varnish, and other results of weathering processes on pediments, pediplains, and peneplains, has a direct bearing on the nature of the surface materials and may dramatically influence the spectral reflectance of specific rock types. 
In some areas this has made interpretation of both aircraft and satellite imagery difficult.

\section{ROCK UNITS DEFINED ON ENHANCED IMAGERY}

\section{METAMORPHIC ROCKS}

The two areas selected to test the applicability of computer-enhanced Landsat imagery in active regional mapping programs are shown on plate $1 C, D$, and plate $2 C, D$. These images illustrate the geological information that can be obtained by using differently enhanced Landsat data. Images made using the ramp-stretch and ratio-stretch methods are particularly complementary to each other. The ramp-CDF stretch images (pls. 1C, $2 C$ ) clearly define topographic relief and drainage lines. In addition, some fundamental differences of terrane reflectance among rock types can be determined on the basis of both color and surface texture. Topographic features are shown even better on images obtained during winter months than on the spring images shown here, as the lower sun angle increases the shadows that define the surface texture. Because of increased color contrast, the CDF contrast-stretch images also show tectonic features more clearly than does the standard Landsat imagery (pl. $1 B$ and pl. $2 B$ ). For example, lineaments that are commonly indicators of faults, or bedding where the strata are folded and differentially eroded, are more clearly visible on plate $2 C$ than on $2 B$. In general, rocks that are dark in outcrop are also dark on the contrast-stretched Landsat images. For example, metabasalt and amphibolite schist (pl. $1 B$ ) appear nearly black on plate $1 C$ in the northern test site. The metamorphosed dark igneous rocks in the southern test site, however, are somewhat lighter in tone (except in cliff shadows), whereas the Oligocene flood basalts (pl. $2 B$ ) show a lighter brown hue on $\mathrm{pl}$. $2 C$. The plutonic rocks, and especially the granitoids in both test areas, are generally light tan or brown, except that, in the northern area, some have a light greenish cast. The calcalkaline plutonic rocks in the southern test area near the Yemen border are generally lighter tan in color than similar rocks in the north. This difference in tone between apparently similar rocks is possibly caused by a thin loessal and alluvial cover that is present where the outcrops tend to form plains. Some quartz diorite is pale blue (qd in pl. $2 C$ ), whereas other batholiths and stocks on pl. $2 D$ are yellow green to olive green.

Alluvium derived from dark rocks appears blue in both test areas; coral reefs and loess are nearly white.

In general, the rock types not readily separated on the ramp CDF stretch image can be separated more readily on the ratio-contrast-stretched imagery. This discrimination capability is especially effective when geologic interpretations are made by using both types of imagery in concert (pl. $1 C, D$ and pl. $2 C, D$ ). In the northern test site, the darker rocks, notably the greenstones, can be separated in the ratio-stretch enhancement because specific classes are grouped into shades of blue, green, red, and orange. The relief, drainage, structural features, and resolution are deemphasized in this product. However, the presence of even sparse vegetation can create a blue-to-purple cast on the ratio-stretch image, as the color and density of the cast are determined by the vegetation density. These dominant hues tend to mask the reflectance signatures of the underlying rock surfaces, and care must be taken not to confuse the two. The distribution of the vegetation can frequently be distinguished by comparison with the characteristic red vegetation signature shown on the standard color-composite Landsat imagery. Examples of vegetative masking can be seen in the northeastern corner of plate $1 D$ in the northern test area and along the west side of the Sarat Plateau at the western edge of plate $2 D$ in the southern test area. The significance of vegetation on rock and soil spectral reflectance has recently been field tested by Siegal and Goetz (1977) by use of a portable field-reflectance spectrometer. Their tests show that the effect of 10 percent cover of manzanita brush in southwestern United States, which is similar to the vegetative cover in western Saudi Arabia, would probably not interfere significantly with rock (andesite) reflectances, whereas in areas of 30 percent or greater vegetation cover, the plant reflectance dominates the scene.

In western Arabia, a native brush covering of more than 10 percent is limited, in general, to the crest and uppermost western flank of the scarp mountains where the 'Asir Mountains intercept the southwesterly monsoon moisture-bearing winds (pl. $2 D)$.

\section{PLUTONIC ROCKS}

In the shield areas of western Arabia, the plutonic rocks generally become darker as the pyribole-biotite content increases. This seems to be a factor influencing the rock discrimination capability in the false-color imagery; for example, compare the biotite hornblende granodiorite (grbh) with the granite (gr) and quartz monzonite (qm) on the ramp CDF stretch image (pl. $1 C$ ). The granite (gr) at Jabal Libān is petrographically similar to the granite southeast of Bi'r Abā al Qazāz; both are predominantly cataclastic and contain two generations of feldspar. Jabal Libān, however, shows a reddish cast on the ratio-stretch image, whereas the granite in the fault zone is nearly black. This difference in color may be due to granulation and weathering in the fault zone or, alternatively, to an increase of metamorphic hornblende in the sheared granite. Indeed, the fault-zone granite has a reflectance similar to that of the granite gneiss west of Wādi Tharī, yet the rocks are of different origin and history (pl. $1 D)$. The explanation for this apparent spectral incongruity is not 
immediately obvious. The quartz monzonite of Jabal $\mathrm{Ra}^{\prime}$ al and nearby intrusive rocks are petrographically similar to the quartz monzonite of Jabal Lahiya at the east edge of plate $1 D$, but the Jabal Lehiya batholith appears darker on the contrast-stretch image and has a lighter, greenish cast when compared with Jabal Ra'al on the ratio-stretch image (pl. $1 D$ ). Here the crest of Jabal Lahiya is an old pediment, probably dating from Oligocene opening of the Red Sea, and weathering has darkened the monzonite. Jabal Ra'al, on the other hand, is a faulted young bornhardt on the Holocene pediment exposed during the last 5 m.y. B.P. and is thus a much fresher surface under active erosion. Why the granite or quartz monzonite (qm) in the top center of plate $1 D$ differs so much from Jabal Lahiya on the eastern edge of plate $1 D$ is not clear. Both batholiths are beveled at $1,200 \mathrm{~m}$ above the Red Sea and both are biotitehornblende quartz monzonite with local granodiorite facies. A single $\mathrm{K}^{40}$-Ar age for Jabal Lahiya is $605 \pm 18$ m.y., whereas for the northern batholith a single $\mathrm{K}^{40}-\mathrm{Ar}$ age is $591 \pm 18 \mathrm{~m} . y$., so both are obviously postkinematic in age. In spite of the obvious field similarity, the northern batholith is light tan on the contrast-stretch image compared with a dark olive green for Jabal Lahiya. Moreover, the northern batholith is black on the ratiostretch image, whereas Jabal Lahiya is a bluish green. The only apparent difference in the two rocks is the presence of large $(1 \mathrm{~cm})$ potassic-feldspar phenocrysts in the northern batholith.

In the southern test area, similar postkinematic circular stocks of biotite-hornblende granodiorite ranging to quartz monzonite (gqm, pl. $2 B$ ) mapped by Greenwood $(1979 a, b)$ are dark blue, bluish black, and bright blue on the ratio-contrast stretch image (pl. $2 D$ ). Likewise, trondhjemite ( $\mathrm{tj}$ ) has two reflectance colors, olive brown and greenish-gray brown on plate $2 D$. Metamorphosed gabbro $(\mathrm{gb})$ and related rocks are blue green (pl. $2 D$ ), and somewhat more turquoise blue on the image of the northern test area east of $\mathrm{Al} \mathrm{Wajh}$ (pl. $1 B, D$ ). From these findings and information from W. R. Greenwood, it appears that many of the igneous units mapped at a 1:100,000-scale can be subdivided when mapped at a larger scale.

The older metamorphosed bedded rocks in the Arabian Shield are mostly mafic volcanic or associated sedimentary rocks now of the amphibolite facies. In the $\mathrm{Al}$ Wajh area they are characterized by bright and varicolored hues on the ratio-stretch image, as might be expected from the variety of source rocks (gdss, sedimentary; gdsv, colluvium, pl. 1D). The metasedimentary rocks appear orange tinted compared with a more mauve blue for the metavolcanic rocks. A bluish tone forming a crescent east of Jabal Libān in the Al Wajh region (west center of pl. $1 D$ ) appears to represent the older metamorphosed sedimentary rocks and flows that have been further metamorphosed in a contact aureole around a small granodiorite intrusion (gds), rather than the reflectance characteristic of vegetation.

Most of the andesitic greenstones and associated metasedimentary rocks on the northeast side of the Najd fault are in the greenschist metamorphic facies (ha, pl. 1D). Their color is similar to that of the metaflows in the vicinity of Al Wajd (gdsv and gdss, pl. $1 D$ ) except for a greenish cast not seen in the Al Wajd metaflows. They underlie a thick series of pelitic metasedimentary rocks $(\mathrm{mu})$, so their identification here is partly based on our knowledge of the stratigraphic position. Some ophiolitic or ultramafic metamorphosed rocks (ub, pl. $1 D$ ) shown by Pellaton (1979) lie within the outcrops of the greenstone; however, the sparse vegetation especially at the mountain crest west of Wādi Thari makes the distinction of these rocks difficult.

A yellow-orange color correlates with known outcrops of what has been designated either graphitic or carbonaceous schist in the field. Most likely these rocks are graphitic if the metamorphism is in the amphibolite facies. However, carbonaceous material in similar rocks has been identified as being derived from blue-green algae on the Sinai Peninsula and has been dated at $934 \pm 80$ m.y. B.P. (Shimron and Brookins, 1974; Shimron and Horowitz, 1972) (carb, marked carbonaceous on pl. $1 D)$. A similar yellow-orange color on the ratiostretch image of the southern area (pl. $2 D)$ demarcates a belt of similar graphitic or carbonaceous metasedimentary rocks near Al Yemen. On the basis of this spectral unit and later field confirmation, it has been possible to correlate this carbonaceous schist unit over an area of 1 degree in latitude (carb, pl. 2D) (Greenwood, 1979a; Anderson, 1978b) and to define its extension southward across the border into Yemen.

The Najd fault zone extends diagonally across plate $1 D$. The areas of sheared rocks within the zone range in width from 5 to $20 \mathrm{~km}$, depending on the bifurcation and coalescence of the various shear zones, and are greenschist-facies schists grading into the lenses of garnet-amphibolite schist and finally into gneisses and granitic rocks. The ability to separate chlorite-sericite schist (sc, scs) from biotitic and amphibolitic schists (am) is not apparent on the ratio-stretch image, but the contrast-stretched image generally shows the higher grades of metamorphic rocks in dark bluish-brown tones and somewhat darker than the greenschist facies (pl. 1C). On the other hand, the amphibolitic schists (am) are easily separated within the fault zones on the ratio-stretched enhanced imagery, even though differences between these units are not apparent even on aerial photographs or from visual inspection from aircraft. The amphibolite schist is also generally darker than the greenschists on the standard simulated falsecolor Landsat imagery (pl. 1B). The enhanced-image pair shown on plate $1 C$ also provides an excellent example for the visualization of the process of granitization. 
Note how the eastern elongated gneiss dome (amg) north of Jabal Ra'al and the north-trending gneiss dome (gn) southwest of Jabal Galab both grade from greenschist into amphibolite and granite or quartz monzonite, the latter being late or postkinematic. Although their lithology is similar, the domes are labeled differently because field investigations show that the north-trending dome is associated with at least two periods of tectonism, whereas the east-elongated dome north of Jabal Ra'al is associated with the Najd fault tectonism-the latest diastrophism of consequence within the shield.

\section{GOSSAN AND LATERITE}

The graphitic or carbonaceous sedimentary rocks and associated andesite and dacite that extend southward along the eastern edge of the Zahrān area include lenses of gossan formed from the weathering of sulfide minerals. A distinctive spectral signature for gossan was identified on the ratio-stretch image where the alteration is exposed over areas large enough to register at the scale of the imagery $(\mathrm{g}, \mathrm{pl} .2 D)$. This gossan overlies massive sulfide deposits or lenses within the metavolcanic and metasedimentary rocks. The sulfide mineralization consists mostly of pyrrhotite and pyrite. The gossan itself is composed of hydrated iron oxides and silica, is locally calcareous, and is brown, buff, and maroon in outcrop. On the ratio-stretch imagery, it is identified by a distinct reddish-orange color, but it is not distinctive on either the standard color-composite Landsat imagery or the contrast-stretch enhancement or even on aerial photographs (pl. $2 A$ and $B$ ). However, a very similar hue marks the outcrop of a deeply weathered, partly lateritized saprolite, which underlies the Sarat volcanic rocks, where reddish-orange color forms a rim around the volcanic rocks located about $100 \mathrm{~km}$ west of the gossans described above (Tl, pl. $2 D$ ). The deeply weathered laterite-saprolite zone is red, yellow, and white in outcrop and composed mostly of kaolinite and quartz but also includes local concentrations of goethite and alunite (Overstreet and others, 1977). The orange-red color is most intense where goethite crops out, as might be expected, but, surprisingly, all the lateritic outcrops show a similar hue.

\section{TERTIARY VOLCANIC ROCKS}

Flood-basalt fields of different ages have previously been found to reflect striking differences in color on the ratio-stretch imagery (Blodget and others, 1975). The only basalt fields within the two test areas studied within this report are the Sarat (Ts on plate $2 C$ and $D$ ), the tips of an outlying prong of Harrat 'Uwayrid east of $\mathrm{Al}$ Wajh, and two small outliers of Harrat 'Uwayridg ( $\mathrm{Tb}$, pl. $1 D)$.
The Sarat lavas are hypersthene-normative basalt, alkali picrite, and alkali olivine basalt. About 20 flows range in age from 29.4 to 24.7 m.y. B.P. (Coleman and others, 1977). On the basis of two samples collected near the test site, the northern Harrat 'Uwayrid is interpreted to be alkalic olivine basalt. A late Miocene age of 7.4 m.y. B.P. has been determined by Richard Marvin of the U.S. Geological Survey. On the ratio-stretch image, the Harrat 'Uwayrid-type basalt is bright blue, whereas the older Sarat lavas are a distinctively different light green-blue hue on the same image. The Sarat lava reflectance is partly obscured by vegetation that imparts a violet cast to much of the upland surface of the flows.

\section{CONCLUSIONS}

Certain types of computer-enhancement techniques significantly increase the geologic interpretability of Landsat satellite data for regional mapping. The two computer-enhanced products that proved most useful in this experiment were color-composite images made from individually contrast-stretched MSS bands and contrast-stretched ratio images. The former provided greater contrast among terrestrial features than could be attained using standard Landsat color-composite imagery and at the same time retained the optimum 79-m resolution. Color-composite images made using stretched-ratio data, on the other hand, generally increased separability of surface materials, but resolution was inherently degraded during the enhancement process. Optimum geologic interpretations can be made if these two image classes are used in concert.

A wide variety of rock types could be distinguished using a combination of both types of data in two Arabian test areas used in this report. Although a complete separation of all the different surface materials could not be accomplished, many spectral units could be related to field-mapped rock units and, thus, could be used to supplement regional geological mapping provided sufficient field work is done on the land surface.

The most important applications of enhanced imagery used in lithologic identification for this region are as follows:

1. Gossan and laterite can be identified readily if exposed in large enough outcrops.

2. Lava sheets, mostly basalt, ranging in age from Oligocene to Holocene can be separated by color for each period of extrusion.

3. Graphitic or carbonaceous schists for which boundaries are difficult to identify on the ground have a distinct color on enhanced imagery.

4. Granitoid exposures can be separated with difficulty by rock type. Some quartz monzonite or granite stocks appear identical from petrographic study but have different colors on the enhanced imagery. Conversely, some granitic rocks showing similar enhanced color have different mineral compositions. 
5. Amphibolite can be separated from greenschist easily, and gneissic granitic infrastructures stand out in the imagery, whereas on the ground or in lowaltitude aerial viewing, they are often indistinguishable from the amphibolite flanks.

\section{REFERENCES CITED}

Alabouvette, B., and Pellaton, C., 1973, Geology and mineral exploration of the Wādī Kamal quadrangle: France, Bureau de Recherches Géologiques et Minières, Saudi Arabian Mission, 45 p., maps and appendixes.

Anderson, R. E., 1978a, Geology of the Wādī Atf quadrangle, sheet 17/43A, Kingdom of Saudi Arabia: Saudi Arabia Directorate General of Mineral Resources Geologic Map GM-30, scale $1: 100,000$.

1978b, Geology of the Mayza quadrangle, sheet 17/43B, Kingdom of Saudi Arabia: Saudi Arabia Directorate General of Mineral Resources Geologic Map GM-31, scale 1:100,000.

Baubron, J. C., Delfour, J., and Vialette, Y., 1976, Geochronological measurements $(\mathrm{Rb} / \mathrm{Sr} / \mathrm{K} / \mathrm{Ar})$ on rocks of the Arabian Shield, Kingdom of Saudi Arabia: France, Bureau de Recherches Géologiques et Minières, Open-File Report 76-JEd-22, 168 p.

Beuf, Serge, Biju-Duval, Bernard, Charpal, Oliver de, Rognon and others, 1971, Les grès du Paléozoique inférieur au Sahara: Paris, Editions Techni, 464 p. (Institut français du Petrole, Collection Sciences et Technique du Petrole, no. 18).

Blodget, H. W., 1977, Lithologic mapping of crystalline shield test sites in western Saudi Arabia using computer manipulated multispectral satellite data: Washington, D.C., George Washington Univ., Ph. D. thesis, $191 \mathrm{p}$.

Blodget, H. W., Brown, G. F., and Moik, J. C., 1975, Geological mapping in northwestern Saudi Arabia using Landsat multispectral techniques: U.S. National Aeronautics and Space Administration Technical Memorandum no. X-58168 (v. I-B, Geology information systems and services), p. 971-989.

Brown, G. F., 1970, Eastern margin of the Red Sea and the coastal structures in Saudi Arabia, in A discussion on the structure and evolution of the Red Sea and the nature of the Red Sea, Gulf of Aden and Ethiopia rift function: Royal Society of London, Philosophical Transactions, ser. A, v. 267, no. 1181, p. 75-87.

1972, Tectonic map of the Arabian Peninsula: Saudi Arabia Directorate General of Mineral Resources Peninsula Map Series Map Ap-2.

Coleman, R. G., Fleck, R. J., Hedge, C. E., and Ghent, E. D., 1977, The volcanic rocks of southeast Saudi Arabia and the opening of the Red Sea: Saudi Arabia Directorate General of Mineral Resources, Bull. 22, p. D1-D30.

Colwell, R. N., ed., 1973, Integrated study of earth resources in the State of California: Berkeley, California University, Space Science Laboratory, $419 \mathrm{p}$. (Progress report to NASA for studies conducted under contract NAS-5-21827.)

Delfour, Jacques, 1970, Le groupe de J'Balah, une nouvelle unité du bouclier arabe: France, Bureau de Recherches Géologiques et Minières Bulletin, 2d ser., sec. 4, no. 4, p. 19-32.

Dow, D. B., Beyth, M., and Hailu, Tsegaye, 1971, Paleozoic glacial rocks recently discovered in northern Ethiopia: Geological Magazine, v. 108 , no. 1, p. $53-59$.

[Fleck, R. J.], 1976, International cooperation in the earth sciences, in U.S. Geological Survey, Geological Survey research 1976: U.S. Geological Survey Professional Paper 1000, p. 302.

Fleck, R. J., Coleman, R. G., Cornwall, H. R., Greenwood, W. R., Hadley, D. G., Schmidt, D. L., Prinz, W. C., and Ratte, J. C., 1976,
Geochronology of the Arabian Shield, western Saudi Arabia: K-Ar results: Geological Society of America Bulletin, v. 87, no. 1, p. 9-21.

Gillmann, Michael, 1968, Primary results of a geological and geophysical reconnaissance of the Jizan coastal plain in Saudi Arabia: American Institute of Mining and Metallurgical Engineers, Society of Petroleum Engineers, Saudi Arabia Section, Regional Technical Symposium, 1968, 2d, Dhahran, Saudi Arabia, Proceedings, p. 189-212.

Girdler, R. W., and Styles, P., 1974, Two stage Red Sea floor spreading: Nature, v. 247 , no. 5435 , p. $7-11$.

Goetz, A. F. H., Billingsley, F. C., Gillespie, A. R., Abrams, M. J., Squires, R. L., Lucchitta, I., and Elston, D. P., 1975, Application of ERTS images and image processing to regional geologic problems and geologic mapping in northern Arizona: California Institute of Technology, Jet Propulsion Laboratory, Technical Report 321597, $188 \mathrm{p}$.

Greenwood, W. R., 1979a, Geology of the Wādī Malahah quadrangle, sheet 18/43D, Kingdom of Saudi Arabia: Saudi Arabia Directorate General of Mineral Resources, Geologic Map GM-39, scale $1: 100,000$

1979b, Geologic map of the Wādi Wassat area, Geologic Map Series, sheet 18/44C: Saudi Arabia Directorate General of Mineral Resources, scale 1:100,000.

[Greenwood, W. R., Hadley, D. G., Anderson, R. E., Fleck, R. J., and Schmidt, D. L.], 1975, Cratonization in the Arabian Shield, in U.S. Geological Survey, Geological Survey research 1975: U.S. Geological Survey Professional Paper 975, p. 271.

Hadley, D. G., 1973a, Geology of the Sahl al Mațān quadrangle, northwestern Hijaz, Kingdom of Saudi Arabia: Saudi Arabia Directorate General of Mineral Resources, Geologic Map GM-6, text, $14 \mathrm{p}$.

1973b, The taphrogeosynclinal J'Balah Group in the Precambrian shield, northwest Saudi Arabia [abs.]: Geological Society of America Abstracts with Programs, v. 5, no. 7, p. 646-647.

1974, Geologic map of the Wayban quadrangle, Kingdom of Saudi Arabia: Saudi Arabia Directorate General of Mineral Resources, Geologic Map GM-7, text, 10 p.

-1975 , Geology of the Qalat as Sawrah quadrangle, sheet 26/38D, Kingdom of Saudi Arabia: Saudi Arabia Directorate General of Mineral Resources, Geologic Map GM-24, text, 28 p.

Overstreet, W. C., Stoeser, D. B., Overstreet, E. F., and Goudarzi, G. H., 1977, Tertiary laterite of the As Sarat Mountains, Asir Province, Kingdom of Saudi Arabia: Saudi Arabia Directorate General of Mineral Resources, Bull. 21, 30 p.

Pellaton, C. P., 1979, Geologic map and section of the Wādĩ Daghalah quadrangle: France, Bureau de Recherches Géologiques et Minières, Saudi Arabia Mission, scale 1:100,000.

Rowan, L. C., Wetlaufer, P. H., Goetz, A. F. H., Billingsley, F. C., and Stewart, J. H., 1974, Discrimination of rock types and detection of hydrothermally altered areas in south-central Nevada by the use of computer-enhanced ERTS images: U.S. Geological Survey Professional Paper 883, 35 p.

Shimron, A. E., and Hornwitz, Ahron, 1972, Precambrian organic microfossils from Sinai: Pollen and Spores, v. 14, no. 3, p. 338-342.

Shimron, A. E., and Brookins, D. G., 1974, RB-Sr radiometric age of late Precambrian fossil-bearing and associated rocks from Sinai: Earth and Planetary Science Letters, v. 24, no. 1, p. 136-140.

Siegal, B. S., and Gillespie, A. R., 1979, Remote sensing in geology: New York, John Wiley and Sons, Inc.

Siegal, B. S., and Goetz, A. F., II, 1977, Effect of vegetation on rock and soil type discrimination: Photogrammetric Engineering and Remote Sensing, v. 43 , no. 2 , p. 191-196. 

